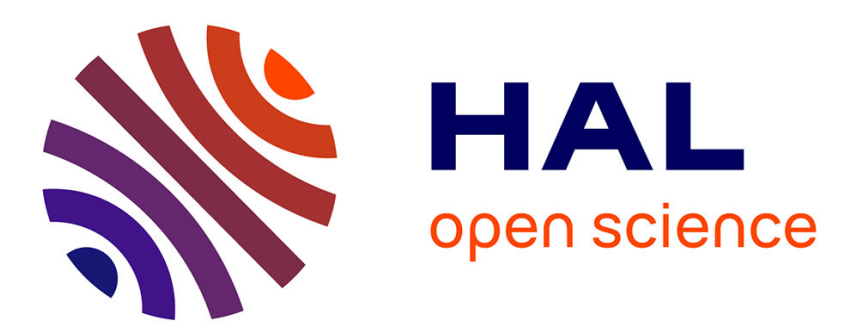

\title{
Towards a "client professionalization" process? The case of the institutionalization of executive coaching in France
}

Scarlett Salman

\section{To cite this version:}

Scarlett Salman. Towards a "client professionalization" process? The case of the institutionalization of executive coaching in France. Journal of Professions and Organization, 2019, 6 (3), pp.1-18. 10.1093/jpo/joz012 . hal-02378432

\section{HAL Id: hal-02378432 \\ https://hal.science/hal-02378432}

Submitted on 25 Nov 2019

HAL is a multi-disciplinary open access archive for the deposit and dissemination of scientific research documents, whether they are published or not. The documents may come from teaching and research institutions in France or abroad, or from public or private research centers.
L'archive ouverte pluridisciplinaire HAL, est destinée au dépôt et à la diffusion de documents scientifiques de niveau recherche, publiés ou non, émanant des établissements d'enseignement et de recherche français ou étrangers, des laboratoires publics ou privés. 
To cite this article: Salman S. (2019), Towards a "client professionalization" process? The case of the institutionalization of executive coaching in France. Journal of Professions and Organization, 6(3):1-18. https://doi.org/10.1093/jpo/joz012

\title{
Towards a "client professionalization" process? The case of the institutionalization of executive coaching in France
}

\begin{abstract}
:
Drawing on the "corporate professionalization" model (Kipping et al., 2006; Muzio et al., 2011) of new strategies adopted by managerial occupations, this paper explores professionalization processes taking into account the role of the client. Based on an analysis of the professionalization of executive coaching, it demonstrates the influence of the client organizations in such processes, at a collective and institutional level. This influence tends to favor new professionalization strategies of differentiation, regulation and dissemination. The paper suggests that this influence does not necessarily limit the power of corporate professionals, at least in the institutionalization phase, especially if we redefine power as consisting "not in restriction and exclusion, but in extension and linking" (Eyal, 2013: 876). Framed primarily to analyze corporate occupations practiced by independent professionals, the "client professionalization" model suggests better taking into account the influence of client organizations in further research on professionalization processes, in line with the research conducted on "client capture" (Dinovitzer, Gunz \& Gunz, 2014; Leicht \& Fennell, 2001). By studying an emergent corporate profession that is practiced by self-employed, solo practitioners and freelancers, which have been largely overlooked in the literature, this paper contributes overall to a more diverse understanding of corporate professions and the ways in which they professionalize.
\end{abstract}

\section{Introduction}

The sociological literature on professions has shown that new, more commercial conceptions of professionalism tend to thrive in a context of neoliberal and cost-containment policies (Muzio and Ackroyd, 2005), and can be interpreted as a move from professionalization "from within", controlled by the occupational group, to professionalization "from above", resulting from forces external to the occupational group (Evetts, 2003). This analysis is relevant to knowledge-based occupations that have proliferated in the management field, because - some scholars have argued - of the very nature of their knowledge, which is fluid and fragmented (Fincham, 2006), and because they prioritize strategies of marketization to develop and commercialize new products for their expertise (Reed, 1996). Against this background, several authors have analyzed the new processes of professionalization that are undertaken by managerial and expert occupations (Muzio et al., 2011; Kipping and Kirkpatrick, 2013; Hodgson et al., 2015; Maestripieri, 2016), that have recently been termed as "corporate professions" (Ackroyd, 2016). The "corporate professionalization" model (Kipping et al., 2006; Muzio et al., 2011), for one, is designed to capture these new processes by showing some of the main strategies of these occupations: new forms of closure (based on competences rather than qualifications), new forms of membership (multi-tiered membership and organizational membership schemes), new legitimization strategies (focused on market value rather than achieving legalistic forms of closure) and new jurisdiction (international rather than national).

So far, this model has focused mainly on corporate professions whose labor market is structured or dominated by large firms, specialized in management consultancy, project management and executive search, in the UK and the US. Following calls for more and 
extended research on corporate forms of professionalism, through the invitation to pay attention to other contexts (Muzio and Kirkpatrick, 2011; Reed, 2018; Bellini and Maestripieri, 2018), this paper contributes to a more diverse and nuanced understanding of the emergent corporate professions and the ways in which they may professionalize. In particular, it studies the professionalization process of corporate occupations that are practiced by selfemployed workers, solo practitioners and freelancers, which have been largely overlooked in the literature. It seems relevant however to explore this kind of process, since the numbers of "independent professionals" - knowledge workers who work as independent contractors in professional and intellectual services - have exploded in recent years in Europe (Rapelli, 2012) ${ }^{1}$. Several studies have examined the strategies adopted by these professionals to overcome market pressures in a context of economic crisis and austerity. They show that the self-employed seek forms of "organized professionalism" (Cucca and Maestripieri, 2014) and turn to organizing and solidarity mechanisms to reduce their increasing vulnerability (Maestripieri and Cucca, 2018), yet seem to "shun the wider practices of professionalization" in order to "maintain a chameleon-like status" (Cross and Swart, 2017: 2). These studies focus however on the individual level of the professionals caught up in their market relationships, even when they study their claims to professionalization (Maestripieri, 2016). As such, they miss the collective and institutional strategies pursued by actors who seek to represent the professional group.

This article explores a different stance with regard to 'new' professionalization processes, by analyzing, on a collective and institutional level, the professionalization of executive coaching - an emergent corporate occupation, practiced primarily by independent consultants in France. Developed in the United States during the 1980s-1990s, coaching was introduced into France early in the 1990s. The coaching service can be defined as "the accompaniment of people in the development of their potential and know-how, within the framework of professional goals", ; and generally consists of a dozen individual, confidential, and periodic interviews between a consultant coach - who is in general external to the company - and a coached manager. Executive coaching provides an action-based type of guidance, and the coach has long been - and often still is - considered as heir to the traditional figure of the confessor, confidant, intellectual guide, and mentor. How has coaching become a new form of professional service paid for by firms for the benefit of their executives? How has it moved, within one generation, from a confidential activity to a wellestablished service (Bresser, 2013; Gray et al., 2016) - and even a prestigious one? How has it given birth to the constitution of a professional group of coaches ${ }^{3}$ ?

The institutionalization of executive coaching in France has been carried out with new strategies and new conceptions of professionalism, more oriented towards the market than towards an institutionally established closure based on qualifications. It corresponds in many respects to a process of "corporate professionalization" (Kipping et al., 2006; Muzio et al., 2011). Coaching is however practiced primarily by independent coaches who are selfemployed or associated in very small structures (limited liability companies of 2 or 3

${ }^{1}$ Between 2000 and 2011, the number of self-employed workers engaged in an activity of an intellectual nature or in the service sector (excluding farming, crafts or retail), rose by more than $82 \%$, whereas numbers for the employed population tended to remain stable (Rapelli, 2012). In the consulting industry in the UK, consultancies with 0-4 employees now account for 93,6\% of the market (figures for 2016) (Clutterbuck, 2017).

${ }^{2}$ Definition by the oldest professional coaching association in France, the Société Française de Coaching (SF Coach).

${ }^{3}$ The existing research on coaching is mostly focused on the results of coaching (Mulvie, 2015) and not on the occupation, its professionals and its market. 
individuals $)^{4}$. These coaches contract directly with client companies or provide their services as subcontractors of large consulting firms. This particularity, which they share with their counterparts in other countries, such as the UK (Cross and Swart, 2017), and which is therefore not peculiar to France, raises questions on the core concept of the "corporate professionalization" model proposed by Muzio et al. (2011): that of organization. As most coaches are not employed by large organizations, the institutionalization process is not influenced by these organizations. In this sense, it contrasts with the "corporate professionalization" model, and the notion of organization takes on a different meaning: it is the large client organizations (and not the employing organizations) that play a major role in the professionalization process and that are the loci of "above" in Evetts' notion of "professionalism from above".

I therefore propose the concept of a "client professionalization" process to emphasize the role of the clients - namely the executive management of large companies who define business expectations, human resources managers who prescribe the service and recruit professionals, and senior executives who are the target of the service - in the professionalization process. This paper thus also draws on a new line of inquiry that has recently been developed around professional-client relations (Sturdy, Werr, Buono, 2009). With the key concept of "client capture", which describes instances when clients become so powerful that professionals lose their autonomy and independence (Dinovitzer, Gunz and Gunz, 2014; Gunz and Gunz, 2008; Leicht and Fennell, 2001), this literature focuses on the influence of the client on professional work and on professionals, but at the practitioner rather than the institutional level. My study, on the other hand, explores the influence of clients on professionalization at an institutional level, by taking the case of independent professionals whose relationships to clients are not mediated by any employing firm. In what ways is the professionalization process of an emergent and independently practiced corporate occupation influenced by the clients and even shaped by their "injunction to ensure professionalism" (Boussard et al., 2010)? What are the effects of this influence on professionalization?

In order to develop the notion of "client professionalization", this article is organized into three sections. The first provides the research design, outlining the data generated and its analysis. The second, the findings section, analyzes the institutionalization process of executive coaching in France, from its introduction in the late 1980s until today. After briefly outlining the obstacles to the autonomization of the activity, in which clients already play a significant role, it presents the strategies of the introducers of coaching and of professional bodies to legitimate and disseminate the new occupation. I use this historical account to make a middle-range theoretical analysis of the influence of clients in the professionalization of emergent corporate occupations that are mostly practiced by independent professionals. Finally, the discussion section compares these results to the main characteristics of the "corporate professionalization" model. It discusses the contribution of the notion of "client professionalization" to a more pluralistic account of the professionalization of "corporate professions". Lastly, the article examines whether the influence of clients undermines the power of "corporate professions" or if it leads to a redefinition of professional power.

\section{Research Design}

This publication is based on an ethnographic study that took place over several years in the 2000s, first in 2002, then between 2006 and 2009, in France. It draws on empirical data generated by interviews, observation, and quantitative data, as well as analysis of secondary documentation. I conducted audio-recorded semi-structured and in-depth interviews with

\footnotetext{
${ }^{4}$ The number of coaches in France was estimated at 3,000 in 2018. Fewer than 5\% are internal coaches employed by client companies such as Renault, EDF, SNCF, etc. These companies also use external coaches.
} 
consultant coaches $(n=45)$, human resources managers who prescribe coaching $(n=16)$ and coached managers $(n=18)$. The 45 coaches were selected to constitute a diverse sample of the professional group. More than half of them were prominent coaches, introducers of coaching in France, founders and key members of the oldest professional association in France, $S F$ Coach $^{5}$, authors of books on coaching, or founders of coaching schools. Interviewing these senior coaches was intended to reach the first generation of coaches and thus to trace the emergence of coaching in France and the strategies of its oldest professional body. The second half of the interviews consisted of: a dozen in-house coaches at large companies (the only ones not to be independent coaches) in a variety of industries (public/private, automobile, energy, rail transportation, telecom, banking), who provided information about the dissemination of coaching in companies, the construction of the "demand", and their position as internal coaches; and ten "ordinary" coaches, not affiliated to a professional association, chosen in order to explore the boundaries of the professional group.

All the interviews lasted around 2 hours, and some of the interviewees (mainly the founders) were interviewed two or three times. The interviews were structured as follows: first a biographical interview (more in-depth in the case of the introducers); secondly a part on professional practices and relations to the clients; and thirdly a part on their role, if any, in the professional association and its strategies. Several observations were also carried out to better understand the professional group's actions and the coaching work. I monitored SF Coach closely for a year, attending evening meetings once a month, participating in their annual colloquium, meeting with senior personnel at the association's office, and scrutinizing their documentation and their directory. Although I encountered a lot of resistance because coaching was a sensitive subject in the corporate environment, this observation was facilitated by the professional association's quest for legitimacy and by its president at the time, who had ties to the University. I also participated in two different coaching training courses ( 9 full days of participant-observation, not counting the many appointments with the organizers and informal conversations with the participants). My study of the professional group of coaches benefited from a quantitative survey that I had launched a few years earlier, in 2002, through a questionnaire that I had drafted and sent to SF Coach members at the time (116 respondents, out of a total of 400 members). The data collected, which were exploited with the software Trideux through descriptive analysis and factorial analysis, enabled me to grasp the emerging field of coaching in the early 2000s.

I also conducted 16 interviews with HR managers in large companies in various industries (construction, chemistry, edition, accounting, telecom, banking). Some of them were in the same company as the in-house coaches interviewed, but the majority was not. This was intentional, so that I could extend my reach. The interview guide covered a biographical part, the history of the introduction of coaching in the firm, the role of the HR manager, the description of the recruitment of coaches, the interpretation of cases that led them to prescribe coaching, and the follow-up of coaching services and of coachees inside the firm. I completed this material with observations at human resources tradeshows dedicated to coaching (10 days over two years).

In 2008 I also launched a quantitative survey of members of the Association Nationale des Directeurs de Ressources Humaines (ANDRH), the main and oldest HR professional association in France, founded in 1947: 221 respondents out of about 4,000 members). The small proportion of answers indicates that there was not keen interest in coaching in the HR community at the time, and precludes generalization of the results, but the 221 answers were enough to be exploited with the software Modalisa, mostly through descriptive analysis. The

${ }^{5}$ http://www.sfcoach.org/ 
survey - associated with the preparation of an event dedicated to "ethics in coaching" - had been supported by SF Coach and driven by a steering committee composed of half coaches, half HR managers (ANDRH members), and myself. I presented the results of the survey in the event on ethics (a one-day conference) attended by coaches and HR professionals. Finally, the 18 interviews conducted with coached managers, some of whom worked in the same companies as the in-house coaches and the HR, covered their career and their work, as well as their experience of coaching, from the prescription or the decision to have a coach, to the choice of the coach and the situation after coaching.

All the interviews were fully transcribed and analyzed by coding transcripts, by attaching keywords and/or themes to different segments in order to structure the 'raw data'. The biographical parts of the interviews have been analyzed so as to avoid the "biographic illusion effect" (Bourdieu, 1994). All the interviews have been considered as "situated linguistic and symbolic constructions" (Demazière and Dubar, 2004: 278) and systematically compared to secondary documentation (books, press analysis, etc.). The interview data, observation material, quantitative data and secondary data are interwoven in the following account of the institutionalization of coaching in France. I use this material to develop a strategic narrative, an account of actors and events, intended, in line with the effort to build theory from history (Stryker, 1996), to ground and illustrate my arguments about the mechanisms that underpin the new form of "client professionalization".

\section{The Influence of Clients on the Institutionalization Process of Executive Coaching in France}

\section{A Contested Activity}

Coaching was "imported" into France from the United States around the end of the 1980s by several French management consultants who had worked as psychotherapists in the 1970s. Among them was Vincent Lenhardt, who set up the first French coaching training in 1989 and published the first French book on the subject in $1992^{6}$. Despite these initiatives, coaching remained confidential for a decade, used only by subsidiaries of US companies like Rank Xerox, and not introduced into French corporations like SNCF and EDF before the turn of the century. Back then, coaching services remained dispersed and invisible to human resources management, because top managers, usually close to Lenhardt's network, used them confidentially. In the French media, the first article on coaching came out in a business magazine in 1988 as an interview of Lenhardt entitled "Managers need a coach!" but was followed by almost ten years of silence. It was broken in 1996 only, with the launching of the first professional coaches association, SF Coach, and two articles in the main intellectual daily, Le Monde. This contrasts with the proliferation of articles on the subject at the beginning of the 2000s (about ten in Le Monde between 1999 and 2001, and at least one in every big newspaper, business or not, during the same period).

The economic and institutional context favored a tendency to individualize consulting practices. Yet initially coaching suffered from being practiced in the shadow of management consulting, and struggled to empower itself in relation to this ambivalent ally. This is a classic dimension of the struggle for a new jurisdiction (Abbott, 1988). Coaches however also encountered the clients' resistance, even if the latter were expressing needs for the service an aspect that has received less attention in the literature. Their first response to that resistance did not adequately allow for the institutionalization of the new occupation.

The first obstacle to the autonomy of coaching stemmed from resistance by more established professionals, such as management consultants. Some former management

\footnotetext{
${ }^{6}$ Les responsables porteurs de sens: culture et pratique du coaching et du team-building. Paris, Insep consulting.
} 
consultants recall that, in the context of restructuring and downsizing of large businesses during the economic crisis of 1993-1994, senior executives approached them with informal requests for individual help. Organizational consultants generally considered the privileged relationship with an executive of the client company as a part of their work. Schein described it in 1969 as a "maieutic relationship", thus distinguishing it from the "provision of expertise". Management consultants had no interest in forfeiting the trust of powerful actors such as senior executives. But some of them, especially women who had been trained in psychology and who were attracted by psychotherapy, wanted to develop what they called "personalized consulting" (before the term coaching spread). At the time, that was not possible, partially because they encountered a second obstacle, which was linked to the clients themselves.

Some of the coaches recall their clients' reluctance to acknowledge the individualized nature of the service received and spoke of a "cultural taboo around individual consultations." Managers feared that being coached would be interpreted as a sign of personal weakness, as the co-founder of the first coaching professional association, a former consultant, recalls:

One of my clients, for whom, clearly, the service consisted of nothing more than interviews, told me: 'If I buy that from you [individual consulting], that clearly means that, in the eyes of others, I don't know. If we're talking about 'consulting' that's OK, as it's understood in the business world, it doesn't mean we don't know; it's that we don't have the time to do it ourselves; it's that this is a type of expertise that we don't have, so it's not a weakness. However, if you're offering to listen to me, that clearly means that I have a weakness, and that's something I can't allow in the eyes of others.

The fear of being stigmatized as "weak", which was accentuated by the "logic of honor" that prevailed at French companies, was also related to the proximity of coaching to two other activities that were considered to have little moral legitimacy in companies: first, outplacement, the personalized accompaniment of managers proposed as a part of downsizing - associated with dismissal - which many aspiring coaches carried out at the beginning of the 1990s; and psychotherapy. The differentiation from outplacement was easier to achieve, as the latter was carried out in the event of a lay-off. Coaches however had to reassure companies and managers, who saw resemblances between coaching and psychotherapy, due to their use of individual and confidential sessions and to the psychological techniques on which coaching is based (Salman, 2014; Gray et al., 2016; Western, 2017). Psychotherapy and the figure of the "shrink" were accused of not being close enough to the preoccupations of the company and of causing fear because they were associated with mental pathology. Additionally, a second type of distrust was related to the boundary between private life and the professional domain, which this service inspired by psychotherapy could call into question. At the employee level, this was the fear of the company's intrusion into the individual's personal life, which could include the fear of manipulation. At management level, companies distrusted the possible relationship of influence between the coach and the managers coached.

These fears were intensified by the charismatic and secretive image that the first coaches exploited, which certainly did not favor professionalization. The introducers of coaching into France tried to lend authority to the figure of the coach and to enhance its prestige, by linking it to the tradition of the "Prince's adviser" and to the more recent "shadow elites" (Wedel, 2009). Lenhardt compared it to "shadow consulting". The service was initially positioned as addressing "directors", the highest level of management in the company hierarchy, or even CEOs. The personality of the coach was valued as a charismatic one, though one in the shadows, like the angel on Matthew's shoulder in Rembrandt's painting, which was reproduced on the cover page of the first French book on coaching. But while this figure may have worked for specific sole practitioners such as Lenhardt to reach the very top 
executives, it precluded access to a wider market. Coaching seemed less like a professional practice than a service strongly tied to the practitioner's personality. This dead-end was all the more real insofar as companies were - and still are - mistrustful of sectarian infiltration. Reports by the French inter-ministerial task force set up to keep a close watch on sects warned of the potential sectarian risks present in professional training and psychotherapy, and have included coaching on their list since 2006.

The account of the obstacles that first hindered the development of coaching as a professional occupation shows the importance of overcoming clients' resistance, in addition to coaches needing to differentiate themselves from competitors. But the initial strategy adopted by the introducers of coaching was too elitist to convince a broader market.

\section{Coaches' Collective Client Professionalization Strategies}

The second half of the 1990s marked a turning point in the emergence of coaching as a professional activity. The broader economic and institutional context was affording opportunities to this new kind of practice, especially since a neo-managerial argumentation progressively developed in the 1990s, in relation to organizational changes in large companies (Boltanski and Chiapello, 2006). But the most decisive development for coaching was collective action, which is key to the institutionalization of new practices in emerging fields (David et al., 2013). A dozen consultants came together in 1996 to found the first professional association of coaches in France, SF Coach, less than three years after the creation of the first federation in the United States, which became international (ICF) in 1995, and four years before the French ICF branch was founded. These were former management consultants or HR managers who quit their company in the context of mergers and restructuring in the mid1990s. They joined forces with some psychotherapists who had failed to secure recognition of their profession in the early 1980s, and had turned to consulting. Most of them were men in the second half of their professional career, although a few women, who had close relations with social elites and/or were involved in psychoanalysis, also played an important role. All of them were well connected to the management of large companies. They all had training in psychology, or had had psychotherapy themselves. Some had been trained in coaching with Lenhardt or had worked with him. They wanted to secure recognition for an individual consulting service that they had failed to commercialize as such in the preceding years. These founders used the form of a professional association for their collective action, which seems particularly appropriate in emerging fields (David et al, 2013). The role of the professional body in the professionalization of corporate occupations has recently been revalued and redefined as an identity project, as in the case of public relations (Reed, 2018), although it seems to weaken in favor of the role of the organizations that employ the professionals (Muzio et al., 2011; Ackroyd, 2016), at a more stabilized stage of institutionalization and at the practitioners' level.

The strategies of SF Coach to have coaching recognized as a professional occupation were a mix of attempts to mimic established professions, and a new approach marked by the quest for legitimacy stemming from clients and rooted in skills and experience rather than in qualifications. These strategies can be classified in five types, which constitute five ways in which professionalization is influenced, from above, by the clients. They characterize a "client professionalization" process, which will be discussed in the final section. The first strategy, the professional rhetoric, based on symbolism (Kipping, 2011) as well as on "theorization" (David et al., 2013), aims at convincing clients of the necessity for coaching, through a mix of moral and economic value-added arguments. The second strategy was the differentiation from other professions, necessary to distinguish the particularities of the new occupation and achieve social closure. It remains flexible however, thus allowing the professionals to practice the activities associated with those professions. It also pursues other goals, such as reassuring clients and not only distinguishing the professionals from competitors. The third strategy, the 
claim of expertise, is based on competencies, experience and professional and personal development, rather than on qualifications. The fourth strategy was regulation, which put a new emphasis on ethics and deontology that are inspired by an "injunction to ensure professionalism" (Boussard et al., 2010) coming from the clients, as a new way of regulating the moral tensions of capitalism in managerial professions (Boltanski and Chiapello, 2006). The fifth and final strategy, dissemination, involves establishing affiliation to clients and building alliances with internal actors inside the client companies.

\section{Convincing Clients through Professional Rhetoric}

SF Coach developed a professional rhetoric that aimed at convincing potential clients of the necessity of coaching. Professional rhetoric plays an important role in professionalization, as discourses contribute to the "social construction of reality" (Berger and Luckmann, 1966). Coaches' rhetoric first relied on symbolism (Kipping, 2011) and started with the adoption of a common term to name the new occupation and distinguish it from existing activities. The word "coaching" was adopted even though it was an English word which generated much debate among the $S F$ coach founders ${ }^{7}$ - because for businesses in France, the American origin symbolized managerial innovations since the Marshall plan (Boltanski, 1981). The optimism attributed to the American culture also made it possible to break away from the idea of suffering and the figure of the psychotherapist that client corporations feared. This was accentuated by the reference to sport, contained in the word "coach". Coaching was presented by its introducers as "developing the potential of a champion", which limited any association of "personal failure" with the fact of having a coach. The sports reference moreover had strong appeal in the economic and political world in the 1980s, where it maintained the meritocratic illusion of fair competition.

Professional rhetoric also relies on "theorization", which consists in specifying generic problems and justifying particular innovations as solutions to these problems (Strang and Meyer, 1993; David et al., 2013). In coaches' rhetoric, theorization was designed to convince potential clients that coaching was the best way to address human problems that hindered their firms' performance. The client-centered orientation of the theorization explains the emphasis on "added-value" in the rhetoric. The same characteristic is found in "corporate professionalization" (Muzio et al., 2011). But moral arguments, constituting a "moral mandate" (Hughes, 1958), were also used to add legitimacy to the new occupation by evoking broader cultural values and altruism, an important feature in emerging fields (David et al., 2013). The rationale of coaching first developed in the 1980s-1990s in response to the "problem" of "managerial skills". It also developed, although to a small extent, around the "problem" of stress at work, which gradually emerged in the French public debate in the 2000s-2010s.

As firms became multinational and more flexible, management scholars and consultants, and the introducers of coaching in France, urged the top management of large companies to expect their senior executives not only to be managers but also to be leaders ${ }^{9}$ or

\footnotetext{
${ }^{7}$ Some consultants trained in clinical psychology defended the French word for "accompaniment" (accompagnement).

${ }^{8}$ Lenhardt, V. (1992). Les responsables porteurs de sens: culture et pratique du coaching et du teambuilding. Paris, Insep consulting.

${ }^{9}$ For instance: Bass B.M., 1985, Leadership and performance beyond expectations, New York, Free Press; Conger J.A, R.A Kanungo (Eds), 1988, Charismatic leadership: the elusive factor in organizational effectiveness, San Francisco, Jossey Bass; Nanus B., 1992, Visionary leadership. Creating a compelling sense of direction for your organization, San Francisco, Jossey Bass; Goleman D., 1998, "What makes a leader?", Harvard Business Review, Nov-Dec, 93-102.
} 
"manager-coaches"10. These publications, as well as coaches' discourses, illustrate the effort to construct a social "problem". A prominent SF Coach member, who founded one of the first coaching training schools, called this "the lack of professionalization of managers":

The majority of managers became managers by accident. (...) There is no possible promotion other than becoming a manager. So, in the end, they become managers to continue with their career... But one in every ten isn't interested in management. It's a job that they are unaccustomed to, that they are bad at, and that they have no motivation to do.

Emphasis was put on the relational abilities that management required, the so-called "soft skills" that top executives (mostly engineers in France) were said to lack and that they needed to acquire in order to become leaders. Once the "problem" was set up, there was a theorization on the "solution". The argument was that management training had failed to develop these skills and that they could be acquired only through a device such as personalized as coaching.

The legitimacy of coaching was linked to the fact that companies required these skills, but that they did not 'help' their managers to develop them. This led to a mix between economic and ethical logics, between "added value" and "moral mandate" in their discourses:

All of a sudden, that managerial culture had to change. Therefore, automatically, it was becoming ethically and economically necessary to accompany managers in this significant change" (my emphasis) (In-house coach at a large industrial company undergoing restructuring)

The mix between "added-value" and "moral mandate" was also found in the second subject of theorization that coaches adopted in the 2000s, in addition to the "managerial skills" theme. Coaches sold their services as a response to what was presented as a new set of problems, "executives' job stress", a theme that was supported by the CGC, the main executives union in France:

I help people manage their stress. (...) They never feel entirely competent. I work with them on their self-esteem. They have identity problems, which, if not resolved, turn them into rigid, unavailable people... (Founder of a coaching school, author of several coaching books)

This discourse enabled coaches, in the latter half of the 2000s, to position themselves on the emerging market for the prevention of so-called "psychosocial risks at work" (stress, burn out, bullying, etc.). Patrick Légeron, a psychiatrist practicing coaching, participated in getting these risks onto the public agenda by co-writing the first report on the subject, commissioned by the French Minister of Labor in 2008, following a series of suicides at work. With regard to that morally charged subject, coaches argued that they were working to promote well-being, a broad cultural value. They demonstrated their altruism while making sure that the client companies were also convinced that their service could enhance management performance and lower the costs related to job stress (such as absenteeism).

\section{Clients' Influence on the Differentiation Process}

The emergence of the coaching segment within the consulting market was characterized by differentiation and distancing strategies, which is typical of the professional segmentation process (Bucher \& Strauss, 1961). The differentiation targeted by the professional group of coaches was however not strict; on the contrary, coaches wanted to be able to stay in the consulting market. The difficulty they faced was laying claim to a specific "jurisdiction" (Abbott, 1988) without closing themselves off to the possibility of practicing these other activities, as they had to satisfy their clients' multiple needs. In their case, their strategy of multiple activities to foster their client loyalty may explain the limited social closure that characterizes "corporate professions" (Ackroyd, 2016).

${ }^{10}$ For instance: Lenhardt V., op. cit.; Albert E., Emery J-L., 1999. Au lieu de motiver, mettez-vous donc à coacher! Paris, Éditions d'organisation. 
Coaching was presented as an alternative to consulting. To quote Lenhardt: "Overall, coaching is the opposite of consulting", as well as some of the many coaches who supported that statement: "Our profession is everything except consulting"; "Coaching doesn't give advice to the customer"; "Coaching does not give solutions or answers"; and "A coach is not an expert"11 (answers to the questionnaire sent to SF Coach members, 2002). The coach's work is not based on the transmission of expert knowledge; it is aimed at facilitating the emergence of the coachee's abilities, thus guiding them in the self-management of their own problems.

Criticism of consulting was nevertheless based less on head-on opposition than on a dialectics. The claim that there was no transmission of expert content was based on an internal differentiation, within consulting, as Schein (1969) suggested, between the "provision of expertise" and the "maieutics" or "process consultation". Coaching was presented as a way of rethinking consulting itself - "a new approach to consulting" 12 -, a better version of consulting, through the method of "maieutic consultation". Coaches tried to "reduce the work of competitors to an (incomplete) version of theirs" (Abbott, 1988), which is usually key to success in inter-professional competition.

As coaches had to reserve for themselves the possibility of practicing other activities in the consulting market, they opted for a final strategy: the complementarity of these activities. They ensured that the boundaries between professional segments were respected:

We don't do consulting like Cap Gemini or Ernst and Young... Sometimes we work alongside those types of firms, but our involvement puts us further upstream. (...) It's a bit like working on people, men, communication and relationships, upstream. (Former outplacement consultant, coach)

The term "upstream" had the purpose of delimiting the segment in which coaches were to secure a specific jurisdiction: the coaching space could be situated "upstream" from the large Anglo-Saxon consulting firms. Complementarity was possibly the only strategy that small or independent structures could adopt in the management consulting market, in which large firms were predominant. Coaches criticized the standardization of consulting methods, which was contrary to the "customized" nature of coaching services:

We often find people disappointed by large organizational firms, customers who were disappointed by working with large firms, such as Mac Kinsey, BCG... where, and I know it, they encountered a lot of intelligence and solutions which were often already complete, and which don't take into account the state of the company to which their advice is being applied, whatsoever. (Former HR manager, co-founder of SF Coach)

Their criticism not only concerned different expertise, but also involved their conception of professionalism. They claimed that "small is beautiful" because closer to clients' needs, referring to the personalization of the service, which they presented as their particularity compared to larger firms. This sharing of the consulting territory mitigated potential conflict with the large consulting firms. It allowed coaches to work as subcontractors for these firms, which was in the interests of both, since the consulting firms wanted to offer coaching services to their clients without employing a coach full time.

The professional rhetoric of coaches was also directed at differentiating themselves from psychotherapy. But here again, the differentiation process was turned towards clients, to reassure them regarding their fears with respect to psychotherapy, rather than aiming to distinguish coaches from the competition of "shrinks". The argument was that coaching was restricted to the "professional" domain, whereas psychotherapy pertained to the "personal"

${ }^{11}$ This does not mean that coaches do not claim to have expertise. Expertise is necessary for the identification of a new occupation. But when they talk about their work, they want to highlight the co-production part of it.

${ }^{12}$ Cohen Daniel, 2002. "Préface", in Caby F., Le coaching. Paris, De Vecchi. 
domain. This distinction authorized the company to take up coaching for its employees, since the aim was to develop their professional abilities, and not to become involved in their personal life. A second argument relates to the distinction between the "patients" of psychotherapists and the "clients" of coaches, who are supposedly "normal":

Our patients in general are in pain, but that's not the case of the people you see at companies. (...) Rather, they are successful people, who are requested at a given point in time to take a step back regarding what they are, because their position is evolving. (Psychiatrist and coach)

This distinction was granted more value with the debate on work stress, because of its potential legal consequences for the companies' management.

\section{Relational Form of Knowledge and Client-Focused Expertise Claim}

In order to have a specific jurisdiction recognized, technical legitimacy and specific knowledge must be established (Abbott, 1988), and an exclusive "license" obtained (Hughes, 1958). As they claimed a specific jurisdiction, the coaching professional associations selected criteria other than qualifications, and valued a relational form of expertise, based on experience and personal growth.

Numerous private training courses in coaching emerged in the second half of the 1990s, demonstrating that coaching was an occupation with its own specific training. The importance of taking a training course was established within the professional group, but it was far from being attained in the early 2000s. A third of the respondents to our survey of SF Coach members in 2002 had not undergone training in coaching (more than half of the promoters of coaching) and many claimed to have "always been a coach". Having followed training in coaching is a criterion widely used by clients today to recruit coaches. We find the trace of this criterion even under the pen of the first-generation coach Pierre Blanc-Sahnoun, who used to defend a naturalized conception of coaching skills: "One does not become a coach: one is born a coach, and one learns one's trade by undergoing training" ${ }^{13}$ (my emphasis). The technical legitimacy of the coach relies on the mastery of help relationship techniques borrowed from psychology and psychotherapy, acquired through practice in the form of role-play. Scholars argued that a relational form of knowledge, in management occupations, made it difficult to grant formal credentials certifying the mastery of an official body of knowledge (Fincham et al., 2007). In the coaching case, the emphasis was on the coach's practice and experience of human relationships, so as to highlight the place of the client in the service delivery. Co-production is found in every kind of service, but coaches claimed it as an integral part of their work, for they use the relationship to the client as a tool in their coaching.

The case of coaching actually presented a mix of new and old professionalization strategies. Despite this fluid form of knowledge, the professional group crossed a turning point with "the diploma strategy" (Ollivier, 2012) in the first half of the 2000s, and attempts to lend academic legitimacy to coaching, to counter accusations of charlatanism. This was evidenced by the creation of university training courses dedicated to coaching ${ }^{14}$, which were moreover much cheaper than private training and enjoyed the institutional label of the university. The attempts to promote academic endorsement of coaching also led to publications by academic publishers in the mid-2000s ${ }^{15}$.

\footnotetext{
${ }^{13}$ P. Blanc-Sahnoun (2010) L'art de coacher.

${ }^{14}$ The first one was created in 2002 at Pantheon-Assas University's business school, by a coach and a management professor.

${ }^{15}$ For instance: Angel P., Amar P., 2005. Le coaching. Paris, Presses Universitaires de France, Collection "Que-sais-Je ?"; Angel P., Moral M., 2006. Coaching, outils et pratiques. Armand Colin, Collection 128, Psychologie.
} 
At the same time, coaches' professional associations ${ }^{16}$ established accreditations and certifications. These certifications can be analyzed as "impersonal devices of judgment" (Karpik, 2010) designed to reduce quality uncertainty related to market opacity, when there is no institutional or external regulation. While calling for the recognition of specific expertise for coaching, the associations retained criteria other than qualifications and valued skills. These criteria were close to the "professional development" valued by the professional body in public relations (Reed, 2018): previous professional experience (external to coaching), supposed to guarantee the coach's understanding of the professional issues the coachee had to deal with; training in coaching or in psychological techniques; values, such as "ethics" and "quality"; the mastery of coaching skills - which were codified by both SF Coach and ICF only in the mid-2000s; and on-going professional supervision. The associations furthermore sought to validate their certifications not only by establishing criteria, but also by ensuring that these criteria were applied, so as to achieve a form of social closure. In 2007, SF Coach decreased its membership from 700 to 250 , in what it claimed to be an intention to "clean up" the profession, with new certification procedures. These actions demonstrate a desire to regulate the market internally by establishing quality labels. Finally, all the associations adopted multi-level membership certifications. The national branch of the ICF also certifies training courses, in addition to the accreditation of individual practitioners, but not coaching firms (again, because most of the coaches are independent workers or practice in very small firms). Accrediting training courses raises similar problems to the introduction of organizational membership that has been studied in the corporate professionalization model (Muzio et al., 2011): not all of the training schools participate; and those that do, then play the lead role in disciplining individual practitioners.

Notwithstanding their differences, which had slowed down the recognition of coaching, the main associations (SF Coach and the French branches of ICF and EMCC) joined forces in the 2010s and in 2012 their leaders and the heads of their "professionalization" sections secured the registration of coaching as one of the "selfregulated professions" of the European Union, after having submitted a White Paper to the European Commission. Above all, in 2015 they achieved the addition of coaching training to the National Register of Professional Certifications (RNCP) of the French Ministry of Labor. SF Coach did not however participate in this, because this association accredits only individuals and not training courses. Coaches seized the opportunity of the institutional context to ask for the addition of their trainings to the RNCP, as the European Parliament had urged France to establish the RNCP in the wider context of the European policy for long-life training. This granted official recognition to those who had been trained in a certified coaching course (most of which are recognized as equivalent to a Bachelor's degree). It also recognized the title of "professional coach", which supplanted that of "executive coach". Without establishing an institutional closure, this title nonetheless granted de facto recognition to the coach's professional activity, on the basis of self-regulation, thus avoiding strict closure based on qualifications.

\section{Regulation as an "Injunction" by Clients to "Ensure Professionalism"}

The main fears expressed by potential clients with regard to coaching were the risks of sectarian affiliation, of collusion between the coach and the coachee, and of intrusion of the company into the employee's private life. Professional associations tried to reassure clients by means of some "impersonal devices of trust" (Karpik, 2010), designed to limit the risks of

${ }^{16}$ Two other societies were created after SF Coach: the French branch of the ICF in 2001, and in 2005 the European Coaching Association, an offshoot of a university program, which in 2012 became the French branch of the European Mentoring and Coaching Council (EMCC). 
malignancy and opportunism in the absence of state regulation. Concerns about "ethics" and "deontology" are central to the professional rhetoric of coaches and are found in dedicated devices. All associations drew up codes of ethics, with common criteria such as "confidentiality" - "the coach agrees not to communicate the content of the sessions to anybody inside the firm" - or "respect for individuals" - "the coach is prohibited from exercising any undue influence". "The coach must take into account both the interests of the coachee and that of his/her organization": this criterion evokes the notion of "coincidence of interest", which tends to replace the notion of "conflict of interest" (Wedel, 2009). The coach must also "guarantee the voluntary nature of the coachee's request" - even though, in reality, most coaching services are prescribed. Apart from the effectiveness of these criteria - which raises the question of how realistic they are - these codes were intended to reassure potential clients, that is, the "prescribers" and recruiters of coaches (HR managers), as well as coachees. The focus on ethics and deontology is set specifically in segments such as management consulting, "where the client/provider interaction is strong and where the immateriality of the result is significant" (Cloet and Vernazobres, 2011: 49). It relates to a form of regulation where the intervention of any coercive third party is not guaranteed in case of non-compliance (Karpik, 2010).

These devices can be interpreted as responses to the "injunction to ensure professionalism" (Boussard et al., 2010) expressed by client organizations that needed to be convinced not only of the advantages of coaching, but also of the quality of this service and its providers. This was particularly important since the group did not enjoy any institutional recognition and therefore depended all the more on that of its clients. Most of the criteria used by the occupational group were designed as ways to reassure companies and therefore to meet their expectations: "The structure of quality coaching conventions is fairly directly modeled, in terms of counter-arguments, on the arguments against coaching" (Cloet and Vernazobres, 2011: 60). These criteria were built from a defensive perspective of "securing professional territory", as in the case of interior designers: "professionalization (...) is thus less of an end in itself underpinned by an offensive logic of gaining advantages, than a defensive social process of collectively claiming legitimacy" (Ollivier, 2012: 243).

\section{Dissemination through the Alliance with Internal Actors inside Client Organizations}

Once the professional territory has been secured, which makes the exchange of services possible, it was necessary to introduce and set up coaching within client organizations. The role of internal actors in organizations in supporting dissemination needs to be emphasized (Kellogg, 2014; Abbott, 2005; Sturdy and Wright, 2011). Rejecting a unitary view of the client being the organization, we can identify three kinds of internal actors who played a role in the dissemination of coaching during the first half of the 2000s: executives who became in-house coaches, HR managers, and senior company executives. The professional group of coaches had to find ways to make alliances with them, to ensure that they were not only "interested" but also "enrolled", to put it in Actor Network Theory terms (Callon, 1984). These actions resulted in the lasting integration of coaching into companies as a tool of HR management.

The first actors in organizations who allied with the professional group of coaches were former executives who became in-house coaches: employees dedicated to full-time or part-time coaching services or to recruiting external coaches. They were not HR managers but executives (sales managers, engineers, bankers, etc.), who had reskilled to become coaches in the second part of their career, usually due to job dissatisfaction, to a glass ceiling, or to a wider context of organizational restructuring or merger that made them lose their executive's position in their firm. They had discovered coaching by having been coached themselves 
when they were still executives. This kind of conversion of corporate executives to coaching is not rare: almost half of all coaches were former executives with a very different background to that of the pioneers of coaching (Salman, 2015). Although most of them had quit their firm to practice as freelancers, a minority (usually women who wanted to keep a more stable job) managed to stay within the firm and become in-house coaches. They were usually the ones who set up coaching in firms and who were in charge of defining the coaching framework and charter. In the first half of the 2000s their company management usually agreed to satisfy these executives' requests for reskilling as a solution to their professional dissatisfaction. It was also believed that these employees' desire to create a new service within the company could benefit it, while reducing the cost of external coaches. In-house coaches already had some relations with external coaches, since they had themselves been coached, and they had expanded these networks through training. Independent professional coaches had - and still have - mixed feelings about in-house coaches: on the one hand, they constitute "unfair competition", but on the other hand, they were instrumental in the take up of coaching in companies. The professional coaching bodies therefore wisely chose to make alliances with them and to accept them as true coaches. Meanwhile, in-house coaches also joined forces amongst themselves in a dedicated organization, to strengthen their position.

The second type of internal actors who have been essential in enabling the dissemination of the new profession were HR managers. They were not immediately in favor of coaching, as some of them - especially seniors, men, in smaller firms - saw it as competition with their own mandate: attending to "the human being in the workplace" 17 . They consequently represented another jurisdictional battle for coaches. The promoters of coaching were careful to pay special attention to these HR professionals, by training them in new practices that familiarized them with the profession. HR managers were led to see the advantages they could derive from integrating coaching as a HR tool. First, the theorization that had presented coaching as key to developing key "managerial skills" of strategic importance to companies at the turn of the 1990s, helped to position it as one of the new "fundamentals of HR management", included in a range of interrelated tools (managerial training, high potential detection, assessment centers, etc.). HR managers could moreover benefit from "taking control" of coaching. One of their concerns was to prevent situations experienced back in the 1990s, with the proliferation of "wild" or "clandestine" coaching, prescribed at the initiative of a senior executive without the HR being informed. By "taking control" of coaching, they would become the "prescribers", the ones who set the rules, who selected and recruited external coaches, who interpreted the situations and decided whether coaching, or another HR tool, was appropriate for an individual or not. Finally, coaching appeared as an opportunity for HR managers to put HR issues on their company's strategic agenda and thus to enhance their status, as in the case of "talent management" (Chuai et al., 2008, Iles et al., 2010), by showing that they were at the leading edge of neo-management. The dissemination was reinforced by mimetic isomorphism (DiMaggio and Powell, 1983): HRs imitated the innovations of other organizations considered as legitimate, in order to improve their own status.

Finally, the support of senior company executives - often close to Christian circles, sensitive to the argument of "humanization" of the company - was key to the dissemination of coaching. The introducers of coaching played an important role in spreading it among these governing bodies of large companies. Their action can be referred to as "affiliation" (David et al., 2013), not to external institutions such as the press, but to the clients themselves. Several

\footnotetext{
${ }^{17}$ According to the data collected through the questionnaire sent to ANDRH in 2008.
} 
coaches published books with CEOs of large groups ${ }^{18}$, and Lenhardt ran management seminars for this audience in a monastery. These meetings with leaders, also organized with the ANDRH, fostered dissemination by "normative" isomorphism (DiMaggio and Powell, 1983), based on individuals frequenting the same professional networks and influenced by the same discourses. The support of top managers and CEO's increased the legitimacy of coaching, both outside their companies and within, where these powerful actors granted decisive support to the initiative of the internal promoters of coaching.

\section{Discussion. Towards a client professionalization model?}

The professionalization of executive coaching in France differs from traditional modes of professionalization in many ways. Drawing on the "corporate professionalization" model (Muzio et al., 2011), I have proposed the term "client professionalization" to denote the market-oriented strategies adopted by independent corporate professionals. To sum up, five main features of this new process emerge from my case study:

- a new legitimization claim through value-added articulated to a moral mandate;

- a new expertise claim based on competences rather than on qualifications, reflected in a new form of membership that grants more value to experience and practice than to credentials;

- a new differentiation process, designed to satisfy clients and to reassure them, by valuing multiple skills rather than searching for a strict social closure;

- a new kind of regulation through codes of ethics that stem from the clients' normative injunctions rather than from the professional group itself;

- a new form of dissemination, relying on collaboration with internal actors inside client organizations rather than on competition.

To take the definition of the "client professionalization" model further and to discuss its use in the literature, I compare it with the "corporate professionalization" model (Muzio et al., 2011).

The first two features of the "client professionalization" model are also key features of the "corporate professionalization" process: legitimization strategies that highlight added value for the client and not only a moral mandate, and forms of closure based on competences rather than qualifications. For the criterion regarding value added, "the tendency (...) to seek more sustained forms of engagement with clients and end users" (Muzio et al., 2011: 455) is amplified in the case of independent workers, who are very dependent on clients in their labor market (Maestripieri and Cucca, 2018) and who seek to control the process of enrolling and keeping clients. The importance attributed to competences is related, according to certain scholars (Clark and Fincham, 2002), to the relational form of knowledge that is typical of management occupations (coaching as well as management consultancy). This has to do with the importance of the client in the service provided: the service has to be personalized, has to take into account the particularities of the client, and has to respond to their needs (or at least to give the impression of doing so). Valuing competencies rather than qualifications reveals that it is more important to convince the client that the service will fit their specific needs, because it is flexible and personalized, than to appear rigid with qualifications that do not speak to the client. This feature is found in every management occupation but all the more so with independent professionals, who tend to personalize their service by linking it to themselves as a person. Both of these characteristics are salient features of the corporate professionalization process but are stronger in the case of a client professionalization process. As for the multi-tiered membership structure, which grants more and more value to

${ }^{18}$ For instance: Lenhardt V., Martin B., Jarrosson B., 1996. Oser la confiance, propos à l'usage des dirigeants. Paris, Insep consulting; Richet A., 2005. Le coaching en interne : à l'aube du développement managérial durable. Paris, Demos, with a preface written by the SNCF's CEO, Louis Gallois. 
experience and practice rather than only to credentials and knowledge, it is also shared with the "corporate professionalization" model. This tends to show, again, the influence of the client in both processes. But in "client professionalization" there is no corporate membership, unlike in the "corporate professionalization" model, although coaching associations accredit training programs, as well as individuals (as in 'classical' professionalization) rather than firms. It also explains another difference with the "corporate professionalization" model with regard to the latter's last characteristic, the fact that the jurisdiction is international rather than national. This is not as developed in a client professionalization process. The internationalization of the jurisdiction is due to the internationalized market of large consulting firms, whereas independent professionals rely on a personal network (Maestripieri and Cucca, 2018), which is harder to globalize, even if clients may also be multinational companies $^{19}$.

Finally, the last three strategies of the "client professionalization" process are not found in the "corporate professionalization" model. First, the differentiation from competing occupations has always been central in professionalization. It still is, but there is no search for a strict closure. This is because of clients' demand for multiple activities, offered essentially by independent professionals who rely heavily on their network of clients. They have to propose multiple services to maintain a portfolio of clients. Secondly, the role of codes of conduct and ethics has increased and has been redefined. These codes act as impersonal devices to foster trust, to avoid malpractice, and to reassure clients in the absence of State regulation. They are more porous to clients' injunctions. Thirdly, the professionalization process relies on making allies of clients, through different strategies targeting different kinds of internal actors: collaborating with internal consultants instead of competing with them; enrolling HR managers and letting them become the new occupation's prescribers; and fostering affiliations with the top management so as to enhance the new occupation's external and internal legitimacy. The alliance and collaboration's strategy is all the more important for independent professionals, who do not have the same resources (reputation, legitimacy, social ties, etc.) as large firms.

The "client professionalization" model has been proposed, first, to account for the professionalization of emergent corporate occupations, where large organizations are not structuring the labor market, unlike in the "corporate professionalization" model. It aims at better understanding the professionalization, at an institutional level, of corporate occupations that are mostly practiced by self-employed workers and freelancers. These independent professionals have been described as so dependent on the market and on their clients, that their professionalization was said to be doomed (Cross and Swart, 2017; Maestripieri, 2016). But that which is relevant at the practitioners' level is different at an institutional level. By looking at the institutionalization of an emergent corporate profession practiced by independent professionals, this paper intends to show that this kind of professional can develop strategies of legitimization, claims relating to expertise, differentiation, regulation and dissemination. These strategies enable them to secure their own professional territory and to make their occupation widely recognized as a new profession. Clients play an important role in this professionalization process, in several ways: they trigger the professionalization itself, by their challenges and "injunctions to ensure professionalism"; they are the main target of the professional rhetoric and theorization work, including all kind of arguments, ranging from value-added to moral issues (the latter probably being reinforced in the case of an

${ }^{19}$ Two of the main coaching's societies in France - ICF and EMCC - are members of international societies that have international strategies. The ICF developed a globalization strategy by establishing chapters in 140 countries (27,000 members worldwide). But, at least in France, the professional jurisdiction remains mostly national. 
emergent occupation, as some scholars have shown (David et al., 2013)); they influence the nature of the differentiation process by favoring a soft social closure and the claim of expertise through co-production; the client-professionals relationship is also strong in the regulation strategy, which relies on codes of ethics that first and foremost respond to clients' expectations; their role is finally key to the dissemination of the profession. Neither the professionals nor the clients are passive in that process. Clients are a major player in the labor market and in the service market of independent professionals, who take that into account and build strategies to gain recognition and some power from the clients as well as against them.

Drawing on these results, speaking of a "client professionalization" process can have a broader ambition. It intends to contribute to capturing the growing place of clients in the professionalization of corporate occupations, whether practiced primarily by independent professionals or not, and whether at an institutional or an individual level. The role of clients in consultants" practice is being studied more and more as "active" (Sturdy et al., 2009; Sturdy and Wright, 2011), and has implications for professionalization. By considering "socalled consumers" as "active" (Ashcraft et al., 2012: 475-476), professionalization is seen as a "branding activity", "best approached as a relationship", leading to explore "how knowledge exclusivity is won through persuasive constructions of work" (Ashcraft et al., 2012: 476). The growing place of the client is also found, at an individual level, in the professionalization of public relations in the UK, where practitioners identify more with their clients than with the professional identity projected by their professional body (Reed, 2018). These alternative conceptions of professionalism, that take into account more the growing place of clients in professionalization, plead for a more pluralistic account of the professionalization of "corporate professions".

These conceptions also nuance the idea that corporate professions should be dismissed as not being professions at all, and that they should only confirm the more general decline of the power of the professions (Ackroyd, 2016). It is significant that coaches were able to secure their professional status. The role of the professional bodies in this process must also be emphasized, even if this role is much bigger at the institutionalization level than it is at the practitioner's level (Reed, 2018). Finally, the question of what kind of power this is, and its extent, is an open one. This brings us to the definition of power. As G. Eyal has shown, the neo-Weberian sociology of professions has focused on a conception of power "understood under the twin forms of monopoly and autonomy" (Eyal, 2013: 875). But Eyal's sociology of expertise pleads for another conception of power, consisting in what he calls "generosity" and "co-production". Following Rose (1992), he conceptualizes "generosity" as the opposite of monopoly, that is, as the ability of a network of expertise to become more influential because its concepts and modes of seeing, doing and judging "can be grafted onto what others are doing, thus linking them to the network and eliciting their cooperation" (Eyal, 2013: 876). Following Rabeharisoa and Callon (2004), "co-production", the opposite of autonomy, expresses the virtue of "involving multiple parties - including clients and patients - in shaping the aims and development of expert knowledge" (Eyal, 2013: 876). Quoting Foucault, Eyal concludes: "power consists not in restriction and exclusion, but in extension and linking" (Eyal, 2013: 876). This conception gives new value to the typical strategies of "client professionalization", especially to differentiation and dissemination, since they can be seen respectively as strategies of "generosity" (through the soft social closure and cooperation with competitors) and "co-production" (through the involvement of multiple internal actors inside client companies). This more interwoven relationship between professionals and clients may then not result in less power for both the expertise and the experts, since it can enhance the latter's authority (Eyal, 2013). This relationship certainly requires other modes of regulation, as in the "client professionalization" model. It is interesting to note that one of the criteria of coaching's code of ethics is close to what J. Wedel (2009) calls "coincidence of interest". This 
is where "client professionalization" can meet the notion of "flexians" (Wedel, 2009), this new kind of professional, consultant or academic that represents business interests and whose activity permeates the boundary between public and private. Wedel suggests that a new approach is needed to analyze "coincidence of interest", whereas the focus has long been on the notion of "conflict of interest". The exploration of the consequences of the more interwoven relationship between clients and professionals, which this paper calls for, may usefully contribute to this reflection.

\section{Conclusion}

Intended to contribute to a better understanding of new modes of professionalization, this article has analyzed the institutionalization process of executive coaching, a corporate occupation practiced primarily by independent professionals, in the context of France, from the 1990s to the mid-2010s. It has shown how the reluctance and fears of potential customers hindered the development of coaching, in addition to the resistance of competing occupations such as consulting. It has also shown that the strategies of the coaching professional associations, concerning legitimization, differentiation, expertise, regulation and dissemination, were mainly driven by their clients' expectations and role in the labor and service market. This study confirms a move from "professionalism from within" to "professionalism from above" (Evetts, 2003). Despite several common features with the "corporate professionalization" model (Muzio et al., 2011), the professionalization process of executive coaching indicates a new model: one, which analyzes more directly the growing role of the client in professionalization. The article has proposed to name this new model a "client professionalization" model. In line with research on "client capture" (Dinovitzer et al., 2014; Gunz \& Gunz, 2008; Leicht \& Fennell, 2001), it demonstrates the influence of the client in professionalization processes, but at an institutional level. The importance of the clients in such processes seems to be more obvious in the case of an occupation practiced outside of large organizations, by independent professionals.

The final section discusses the use of the new model by drawing a detailed comparison with the "corporate professionalization" model. It shows that the most specific features of "client professionalization" lie in the strategies of differentiation (achieving a soft social closure so as to maintain a portfolio of clients through multi-activity), of regulation (through "impersonal devices of trust" inspired by the clients" "injunction to ensure professionalism") and of dissemination (through alliances with internal actors inside client organizations). The "client professionalization" model is framed primarily to analyze the institutionalization of new corporate occupations practiced by independent professionals. It calls for further empirical cases to be analyzed to test this template and its heuristic nature. It already contributes, alongside other scholars (Ashcraft et al., 2012; Reed, 2018), to a more nuanced and diverse understanding of the notion of "corporate professions" (Ackroyd, 2016) and of the ways in which they may professionalize. Finally, it suggests that the more interwoven relationship between clients and professionals, and its influence on professionalization, does not necessarily limit the power of professionals, especially if we define power as consisting "not in restriction and exclusion, but in extension and linking" (Eyal, 2013: 876). 
Acknowledgements: I'd like to thank the conveners of EGOS Standing Working Group 8 "Management, Occupations and Professions", of SASE Network D "Professions and Professionals in a Globalizing World" and of ISA RC 52 "Sociology of Professional Groups", as well as the anonymous reviewers of Journal of Professions and Organization, and David Brock, for their useful comments and suggestions on previous versions of this text.

\section{References}

Abbott, A. (2005). Linked ecologies: States and universities as environments for professions. Sociological Theory, 23 (3), 245-274.

Abbott, A. (1988). The System of Professions: An Essay on the Division of Expert Labor. Chicago: University of Chicago Press.

Ackroyd, S. (2016). Sociological and organisational theories of professions and professionalism. In: Dent M, Bourgeault IL, Denis JL, Kuhlmann E (eds) The Routledge Companion to the Professions and Professionalism. London: Routledge, 15-30.

Ashcraft, KL., Muhr, SL., Rennstam, J., Sullivan, K. (2012). Professionalization as a branding activity: Occupational identity and the dialectic of inclusivity-exclusivity. Gender, Work and Organization 19(5): 467-488.

Bellini, A., Maestripieri, L. (2018). Professions within, between and beyond. Varieties of Professionalism in a Globalizing World. Cambio, 8(16): 5-15.

Berger, P., Luckmann, T., (1966). The Social Construction of Reality, New York: Penguin Books.

Blanc-Sahnoun, P., (2010, [2006]). L'art de coacher. Méthode, cas pratiques et outils, Paris, Dunod.

Bourdieu, P. (1994). Raisons pratiques: sur la théorie de l'action. Paris, Seuil.

Boltanski, L. (1981). America, America... Le plan Marshall et l'importation du management. Actes de la recherche en sciences sociales, 38, 19-41.

Boltanski, L., Chiapello, È. (1999/2006). The new spirit of capitalism. Translation of Le nouvel esprit du capitalisme, Paris, Gallimard/Verso, London.

Boussard, V., Demazière, D., Milburn, P. (dir.) (2010). L'injonction au professionnalisme, Rennes, Presses Universitaires de Rennes.

Bresser, F. (2013) Coaching across the Globe. Norderstedt: Books on Demand.

Bucher R., Strauss, A. (1961). Professions in Process. American Journal of Sociology, 66 (4): 325-334.

Callon M. (1984). Some Elements of a Sociology of Translation: Domestication of the Scallops and the Fishermen of St Brieuc Bay. The Sociological Review, 32(1): 196-233.

Chuai, X., Preece, D., Iles, P. (2008). Is talent management just "old wine in new bottles"? The case of multinational companies in Beijing. Management Research News, 31(12): 901-911.

Clark, T., Fincham, R. (eds) (2002). Critical Consulting. Oxford: Blackwell.

Cloet, H., Vernazobres, P. (2011). Le marché français du coaching. Zoom sur les conventions de qualité. Revue Internationale de Psychosociologie, 42, 39-69.

Clutterbuck, E. (2017). IBISWorld Industry Report M70.229: Management Consultants in the UK. March 2017 ed.: Ibis World.

Cross, D., Swart, J. (2017). Professional liminality: Independent consultants spanning professions. ST 08: Management, Occupations and Professions as Contested Terrains, 33rd EGOS Colloquium, Copenhagen.

Cucca, R., Maestripieri L. (2014). Architects and consultants between formal regulation and organised professionalism. CAMBIO, 7, giugno, 25-40.

David, R., Sine, W., Haveman H. (2013). Seizing Opportunity in Emerging Fields: How Institutional Entrepreneurs Legitimated the Professional Form of Management Consulting. Organization Science, 24(2): 356-377. 
Dinovitzer, R., Gunz, H., Gunz, S. (2014). Unpacking client capture: Evidence from corporate law firms. Journal of Professions and Organization, 1, 99-117.

DiMaggio, P., Powell, W. (1983). The Iron-Cage Revisited: Institutional Isomorphism and Collective Rationality in Organizational Field. American Sociological Review, 48: 147160 .

Demazière, D., Dubar, C. (2004) [1997] Analyser les entretiens biographiques. Québec, Presses de l'Université Laval.

Evetts, J. (2003). Explaining the construction of professionalism in the military: history, concepts and theories. Revue Française de Sociologie, 44, 4, 759-776.

Eyal, G. (2013). For a Sociology of Expertise: The Social Origins of the Autism Epidemic. American Journal of Sociology 118 (4): 863-907.

Fincham, R. (2006). Knowledge work as occupational strategy: comparing IT and management consulting. New Technology, Work and Employment 21: 16-28.

Fincham, R., Clark, T., Sturdy, A., Handley, K. (2007). Knowledge narratives in management consultancy and professional services. In: Muzio D, Ackroyd S, Chanlat JF (eds) New Directions in the Study of Expert Labour: Medicine, Law and Management Consultancy. London: Palgrave.

Gray, D., Garvey, D., Lane, D. (2016). A Critical Introduction to Coaching and Mentoring. London: Sage.

Gunz, H., Gunz, S. (2008). Client capture and the professional service firm. American Business Law Journal, 45, 685-721.

Hodgson, D., Paton, S., Muzio, D. (2015). Something Old, Something New? Competing Logics and the Hybrid Nature of New Corporate Professions. British Journal of Management, 26 (4), 745-759.

Hughes, E. C. (1958). Men and their work. Glencoe, The Free Press.

Iles, P., Preece, D., Xin, C. (2010). Talent management as a management fashion in HRD: towards a research agenda. Human Resource Development International, 13(2): 125145.

Kellogg, K. (2014). Brokerage professions and implementing reform in an age of experts. American Sociological Review, 79 (5), 1-30.

Karpik, L. (2010). Valuing the unique. The economics of singularities. Princeton University Press.

Kipping, M. (2011). Hollow from the start? Image professionalism in management consulting. Current Sociology 59 (4): 530-550.

Kipping, M., Kirkpatrick, I. (2013). Alternative Pathways of Change in Professional Services Firms: The Case of Management Consulting. Journal of Management Studies, 50 (5), 777-807.

Kipping, M, Kirkpatrick, I, Muzio, D. (2006). Overly controlled or out of control? Management consultants and the new corporate professionalism. In: Craig J (ed) Production Values: Futures for Professionalism. London: Demos.

Leicht, K. T., Fennell, M. L. (2001). Professional work: A sociological approach. Malden, MA: Blackwell.

Maestripieri, L., Cucca, R. (2018). Small is beautiful ? Emerging organizational strategies among Italian professionals, Canadian sociological review.

Maestripieri, L. (2016). Professionalization at work: The case of Italian Management Consultants, ephemera.

Mulvie, A. (2015) The Value of Executive Coaching. Oxford; New York: Routledge.

Muzio, D., Hodgson, D., Faulconbridge, J., Beaverstock, J, Hall, S. (2011). Towards corporate professionalization: The case of project management, management consultancy and executive search. Current Sociology 59 (4): 443-464. 
Muzio, D., Kirkpatrick, I., (2011) Introduction: Professions and organizations - A conceptual framework. Current Sociology 59(4): 389-405.

Muzio D., Ackroyd S. (2005). On the consequences of defensive professionalism: The transformation of the legal labour process. Journal of Law and Society 32(4): 615-642.

Ollivier, C. (2012). Division du travail et concurrences sur le marché de l'architecture d'intérieur. Revue française de sociologie, 53, 2, 225-258.

Rabeharisoa, V., Callon, M. (2004) Patients and Scientists in French Muscular Dystrophy Research, in Jasanoff S., States of Knowledge: The Co-production of Science and Social Order, London: Routledge, 142-160.

Rapelli, S. (2012). European I-Pros: A study. EFIP.

Reed, M.I. (1996). Expert power and control in late modernity: an empirical review and theoretical synthesis. Organization Studies, 17 (4), 573-597.

Reed, C. (2018). Professionalizing corporate professions: professionalization as identity project, Management Learning, 49 (2), 222-238.

Rose, N. (1992). Engineering the Human Soul: Analyzing Psychological Expertise. Science in Context 5, 2: 351-369.

Salman, S. (2014). Un coach pour battre la mesure? La rationalisation des temporalités de travail des managers par la discipline de soi. Revue d'anthropologie des connaissances, 8, 1, 97-122.

Salman, S. (2015). Le temps des coachs ? Trajectoires typiques d'une figure du «nouvel esprit du capitalisme ». Travail et emploi, 143, 59-73.

Schein, E. H. (1969). Process consultation: Its role in organization development. New York, Addison-Wesley.

Strang, D, Meyer, JW (1993) Institutional conditions for diffusion. Theory and Society. 22:487-511.

Stryker, R. (1996). Beyond history versus theory: Strategic narrative and sociological explanation. Sociol. Methods Res. 24:304-352.

Sturdy, A., Werr, A., Buono, A. F. (2009). The client in management consultancy research: Mapping the territory. Scandinavian Journal of Management, 25, 247-252.

Sturdy, A., Wright, C. (2011). The active client: The boundary-spanning roles of internal counsultants as gatekeepers, brokers and partners of their external counterparts. Management Learning, 42(5): 485-503.

Western, S. (2017) The Key Discourses of Coaching, in T. Bachkirova, G. Spence and D. Drake (eds) The Sage Handbook of Coaching, 42-61. London: Sage.

Wedel, J. R. (2009). Shadow Elite: How the World's New Power Brokers Undermine Democracy, Government, and the Free Market. Basic Books. 